\begin{tabular}{|c|c|c|}
\hline CaM落 & $\begin{array}{l}\text { Construction and Material Journal } \\
\text { e-ISSN 2655-9625, http://jurnal.pnj.ac.id/index.php/cmj }\end{array}$ & $\begin{array}{l}\text { Volume } 1 \text { No. } 2 \\
\text { Juli } 2019\end{array}$ \\
\hline
\end{tabular}

\title{
ANALISIS MANAJEMEN RISIKO PADA PROYEK PEMBANGUNAN JEMBATAN
}

\author{
Debbi Rivida M(1), Andi Tenrisuki T(2), A’isyah Salimah ${ }^{(3)}$ \\ ${ }^{1,2}$ Fakultas Teknik Sipil dan Perencanaan, Universitas Gunadarma, Jalan Margonda Raya No.100, \\ Depok 16424, Jawa Barat, , email: dividamandasari@gmail.com \\ ${ }^{3}$ Dosen Jurusan Teknik Sipil, Politeknik Negeri Jakarta, Kampus UI Depok, Telp. 021-7270036, email: \\ aisyah.salimah@sipil.pnj.ac.id
}

\begin{abstract}
ABSTRAK
Pekerjaan konstruksi merupakan salah satu pekerjaan yang mempunyai risiko tinggi terutama pada tahap pelaksanaan konstruksi, tidak terkecuali dalam pekerjaan pelaksanaan konstruksi jalan dan jembatan. Risiko dapat memberikan pengaruh terhadap produktivitas, kinerja, kualitas dan biaya dari proyek. Dalam mengatasi risiko dibutuhkan manajemen risiko. Manajemen risiko merupakan proses pengukuran atau penilaian risiko serta pengembangan strategi pengelolaannya. Tujuan penelitian ini adalah dilakukan identifikasi risiko, analisis risiko dan respon risiko pada pelaksanaan proyek konstruksi jembatan. Berdasarkan identifikasi faktor risiko yang didapat dari studi literatur dan divalidasi oleh pakar diperoleh 69 faktor. Dilanjutkan analisa risiko dengan melakukan uji validitas dan reliabilitas sehingga faktor risiko tereduksi sebanyak 9 faktor dan analisa level risiko untuk mendapatkan risiko dominan, risiko dominan yang diperoleh terdapat 4 faktor dominan yaitu faktor risiko yang paling tinggi dengan bobot 11,657 adalah kondisi lokasi site yang sulit, selanjutnya kesalahan estimasi waktu pelaksanaan proyek dengan bobot 10,886, ketidaktersediaan material dengan bobot 10,657, dan keterlambatan pengiriman material dari suplier dengan bobot 10,400. Dilanjutkan dengan melakukan validasi terhadap pakar pada keempat faktor dominan. Berdasarkan hasil kuesioner tahap ketiga ini seluruh pakar setuju dengan keempat faktor dominan yang mempengaruhi terhadap pelaksanaan konstruksi jembatan.
\end{abstract}

Kata kunci: manajemen risiko, jembatan, risiko dominan

\section{PENDAHULUAN}

Jembatan merupakan salah satu prasarana penting untuk melewatkan kendaraan lalu lintas, memiliki peran yang sangat penting untuk melanjutkan program pembangunan ekonomi Indonesia dan menyebarkan pusat-pusat pertumbuhan ekonomi baru, (Zainuddin,2010). Namun pekerjaan konstruksi merupakan salah satu pekerjaan yang mempunyai risiko tinggi terutama pada tahap pelaksanaan konstruksi, tidak terkecuali dalam pekerjaan pelaksanaan konstruksi jembatan, (Pedoman Pelaksanaan K3 untuk Konstruksi Jalan dan Jembatan, 2006).

Risiko dapat memberikan pengaruh terhadap produktivitas, kinerja, kualitas dan batasan biaya dari proyek. Walaupun suatu kegiatan telah direncanakan sebaik mungkin, namun tetap mengandung ketidakpastian bahwa nanti akan berjalan sepenuhnya sesuai rencana, (Labombang, Mastura, 2011).

Manajemen resiko proyek adalah seni dan ilmu untuk mengidentifikasi, menganalisis, dan menanggapi resiko di seluruh kehidupan suatu proyek dan kepentingan terbaik tujuan pertemuan proyek. Manajemen resiko sering terabaikan dalam proyek, tetapi dapat membantu meningkatkan kesuksesan proyek dengan membantu proyek-proyek baik inisiasi, lingkup proyek, dan mengembangkan perkiraan realistis. 
Tujuan dari penelitian ini adalah melakukan analisis risiko untuk menentukan risikorisiko apa saja yang terdapat pada proses pelaksanaan pembangunan jembatan dan mengetahui respon risiko dari risiko yang paling dominan yang terjadi pada pelaksanaan pembangunan jembatan.

\section{METODE PENELITIAN}

Data yang dipergunakan dalam penelitian ini adalah data-data yang diperoleh dari studi literatur dan penyebaran kuesioner kepada pihak-pihak yang bersangkutan dibidang konstruksi jembatan dan risiko guna melengkapi analisis yang dilakukan.

Risiko yang mungkin terjadi pada proyek konstruksi jembatan akan di identifikasi dengan metode check list faktor risiko yang didapatkan untuk diverifikasi kembali oleh pakar dari peneliti sebelumnya, selanjutnya dituangkan dalam bentuk kuesioner yang akan diberikan pada responden. Olah data dari kuesioner dengan metode skala likert diharapkan dapat menentukan risiko mayor (major risk). Risiko mayor yang bersifat kuantitatif dan berpengaruh pada risiko proyek jembatan akan dianalisis dengan metode quantitaif risk analysis.

Proyek konstruksi dipengaruhi oleh banyak sumber risiko yang dapat menyebabkan ketidakpastian. Sehingga ketidakpastian tersebut dapat mempengaruhi risiko proyek konstruksi jembatan. Ketidakpastian ini dapat di analisis dengan perkalian frekuensi dan dampak sehingga diketahui level risiko.

Kerangka konsep penelitian proyek konstruksi pada jembatan yang telah diuraikan di atas dapat digambarkan sebagai berikut:

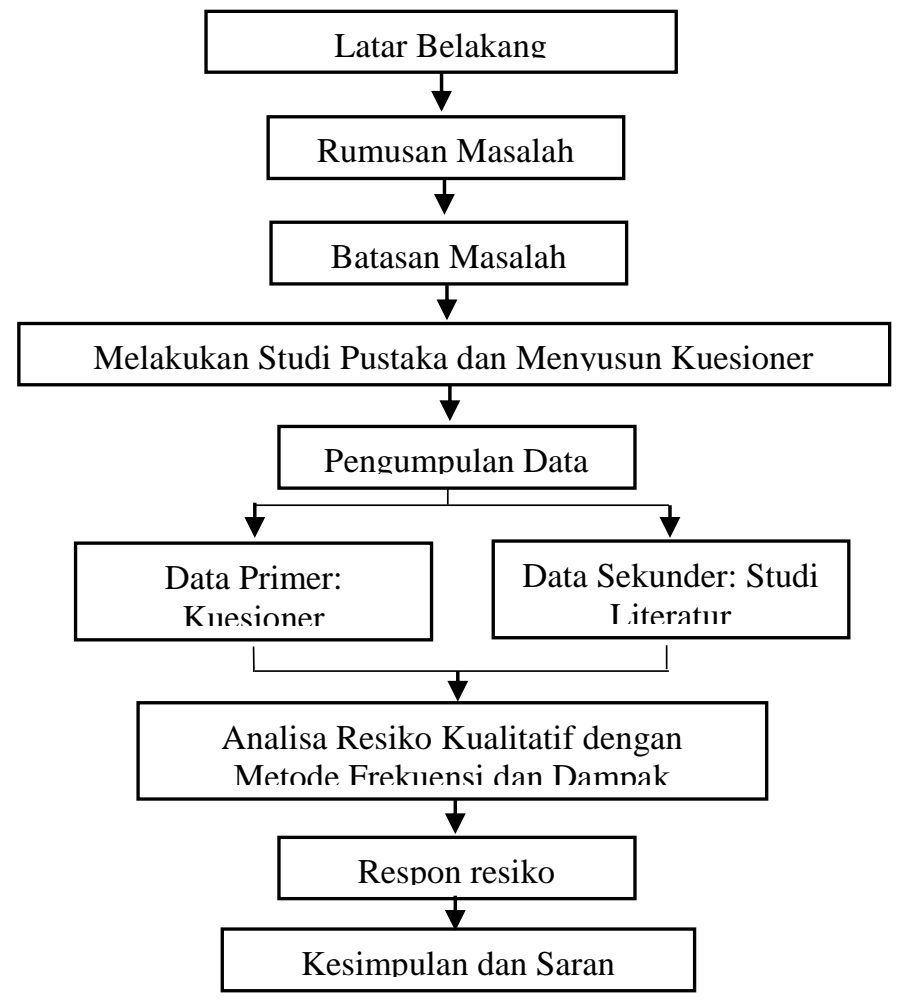

Gambar 2. Diagram Alir Proses Penelitian 


\section{Data Kuesioner Tahap 1}

Kuesioner tahap pertama berisi variabel yang terdiri dari peristiwa risikoyang didapat dari hasil studi literatur sebanyak 83 faktor yang disampaikan ke pakar untuk di validasi. Pakar yang mengembalikan kuesioner dan bersedia dijadikan sebagai narasumber adala sebanyak 5 (tiga) orang, sebagai berikut:

Tabel 1. Data Profil Pakar untuk Validasi Kuesioner Tahap Pertama

\begin{tabular}{lllll}
\hline No. & Pakar & Posisi & Pendidikan & Pengalaman \\
\hline 1. & Pakar 1 & Site Manager & S1 & 15 tahun \\
2. & Pakar 2 & General Manager & S1 & 10 tahun \\
3. & Pakar 3 & Manager & S1 & 10 tahun \\
4. & Pakar 4 & General Manager & S1 & 18 tahun \\
5. & Pakar 5 & Manager & S1 & 12 tahun \\
\hline
\end{tabular}

Sumber: Hasil Olahan

\section{Data Kuesioner Tahap 2}

Kuesioner tahap 2 dilakukan penyebaran kuesioner kepada stakeholder yang berkaitan dengan proyek pembangunan jembatan. Jumlah kuesioner yang disebarkan kepada responden adalah sebanyak 40 (empat puluh) kuesioner. Jumlah sampel responden tersebut diambil dari pendekatan sesuai formulasi Slovin.

$$
n=\frac{N}{1+N e^{2}}
$$

Dimana:

$\mathrm{n} \quad=$ Jumlah sampel/responden

$\mathrm{N}=$ Jumlah pihak terlibat dalam pelaksanaan proyek jembatan

$\mathrm{e} \quad=$ Tingkat kesalahan pengambilan sampel (5\%)

Dari 40 kueisoner tersebut, yang mengembalikan adalah sebanyak 35 (tiga puluh lima) orang.

Tabel 2. Data Profil Responden

\begin{tabular}{cccc}
\hline No & \multicolumn{1}{c}{ Uraian Profil } & $\begin{array}{c}\text { Jumlah } \\
\text { Sampel }\end{array}$ & Persentase \\
\hline 1 & Pendidikan terakhir: & & \\
& a) Diploma & 0 & $0 \%$ \\
& b) Sarjana (S1) & 35 & $100 \%$ \\
& c) Pasca Sarjana (S2) & 0 & $0 \%$ \\
$2 \quad$ Lama bekerja di bidang konstruksi: & & $17,14 \%$ \\
& a) $<5$ tahun & 6 & $51,43 \%$ \\
& b) 5 - 10 tahun & 18 & $31,43 \%$ \\
\hline
\end{tabular}

Sumber: Hasil Olahan 


\section{Identifikasi Risiko}

Pengolahan data identifikasi risiko dilakukan dengan mentabulasi hasil data yang diperoleh. Variabel yang tidak signifikan dan harus dihilangkan adalah variabel yang tidak disetujui oleh minimal 3 responden pakar.

Dari hasil evaluasi data yang diklarifikasi dan divalidasi oleh pakar terhadap 83 (depalan puluh tiga) variabel yang disampaikan, maka didapat 69 (enam puluh sembilan) variabel yang disetujui menjadi variabel yang signifikan untuk disampaikan kepada responden, dimana faktor risiko tereduksi sebanyak 14 (empat belas) variabel dari usulan semula.

\section{Uji Validitas dan Reliabilitas}

Uji validitas dan reliabilitas ini dilakukan terhadap hasil perkalian tingkat pengaruh risiko (dampak) dengan tingkat frekuensi dampak.

Uji validitas dilakukan perbandingan antara $r$ hitung dengan $r$ tabel produk momen. Kemudian dilakukan pengambilan keputusan sebagai berikut:

1. $\mathrm{r}$ hitung $>\mathrm{r}$ tabel produk momen, maka variabel tersebut adalah valid.

2. $\mathrm{r}$ hitung $<\mathrm{r}$ tabel produk momen, maka variabel tersebut adalah tidak valid.

Untuk menguji reliabilitas variabel dilakukan cara pengambilan keputusan dengan menghitung nilai akhir cronbach's alpha. Pada nilai cronbach's alpha dapat dikatakan baik atau reliabel mengacu pada kaidah Guiltford seperti tabel berikut ini:

Tabel 3. Kaidah Reliabilitas Guiltford

\begin{tabular}{ll}
\hline Kriteria & Koefisien Reliabilitas \\
\hline Sangat Reliabel & $>0,9$ \\
Reliabel & $0,7-0,9$ \\
Cukup Reliabel & $0,4-0,7$ \\
Kurang Reliabel & $0,2-0,4$ \\
Tidak Reliabel & $<0,2$ \\
\hline Sumber: Kuncono, 2005
\end{tabular}

Berdasarkan analisa reliabilitas nilai akhir cronbach's alpha sebesar 0,967, yaitu cronbach's alpha lebih besar dari 0,9, sehingga hasil data tersebut sangat reliabel. Dengan demikian, dari hasil uji validasi dan reliabilitas, variabel data semula berjumlah 69, tereduksi menjadi 60 variabel.

\section{Uji Normalitas}

Uji normalitas merupakan metode pengujian sampel untuk mengetahui tingkat kenormalan suatu data jawaban dari responden. Tujuannya adalah untuk mengetahui distribusi data dalam suatu variabel yang digunakan dalam penelitian, yang selanjutnya akan diambil keputusan apakah pengolahan data akan menggunakan parametrik atau non parametrik. Statistik parametrik memerlukan terpenuhinya banyak asumsi, sehingga data yang akan dianalisa harus terdistribusi normal, sedangkan statistik non parametrik 
tidak menuntut terpenuhi banyaknya asumsi, sehingga dapat terdistribusi secara bebas (distribution free). Uji terhadap distribusi data ini dilakukan dengan Uji KolmogorovSmirnov. Kriteria pengujian pada Uji Kolmogorov-Smirnov, dengan hipotesis sebagai berikut:

1. Data terdistribusi normal, jika angka signifikan Uji Kolmogorov-Smirnov Sig > 0,05 .

2. Data tidak terdistribusi secara normal, jika angka signifikan Uji KolmogorovSmirnov Sig $<0,05$.

Berdasarkan Uji Kolmogorov-Smirnov pada penelitian bahwa sebagian nilai Kolmogorov-Smirnov berada diatas maupun dibawah 0,05. Ini berarti bahwa sebagian data sampel terdistribusi tidak normal maupun normal.

\section{Analisa Level Risiko}

Analisa level risiko dilakukan terhadap indeks level risiko. Indeks level risiko dibagi dalam 3 (tiga) level. Pembagian 3 level tersebut dievaluasi berdasarkan rentang kelas yang dihitung dari selisih nilai tertinggi dengan nilai terendah, yang kemudian hasil selisih tersebut dibagi 3 sesuai levelnya.

Tabel 4. Nilai Level Risiko

\begin{tabular}{lc}
\hline \multicolumn{1}{c}{ Level Risiko } & Rentang Nilai \\
\hline Risiko Tinggi (H) & $11,657-9,600$ \\
Risiko Moderat (M) & $9,600-7,543$ \\
Risiko Rendah (L) & $7,543-5,486$ \\
\hline Sumber: Hasil Olahan &
\end{tabular}

\section{HASIL DAN PEMBAHASAN}

Berdasarkan hasil penelitian yang diperoleh melalui tahapan proses penelitian maka risiko yang teridentifikasi dalam pelaksanaan konstruksi jembatan yang telah divalidasi oleh pakar didapat 69 variabel. Setelah dilakukan validasi pakar dilakukan uji validitas dan reliabilitas, berdasarkan hasil uji validitas dan reliabilitas dari 69 variabel terdapat 9 variabel yang tidak valid, sehingga jumlah varibel menjadi 60 variabel. Analisa level risiko dilakukan terhadap indeks level risiko, berdasarkan hasil dari analisa level risiko didapat risiko tinggi yaitu 4 faktor, risiko moderat didapat 27 faktor dan untuk level risiko yang rendah didapat 29 faktor.

Berikut ini adalah hasil evaluasi perhitungan level risiko:

Tabel 5. Hasil Perhitungan Level Risiko

\begin{tabular}{llcc}
\hline No & \multicolumn{1}{c}{ Peristiwa Risiko } & Mean & $\begin{array}{c}\text { Level } \\
\text { Risiko }\end{array}$ \\
\hline R3 & Fluktuasi Inflasi. & 7,200 & $\mathrm{~L}$ \\
R4 & Fluktuasi valuta asing. & 7,857 & $\mathrm{M}$ \\
R5 & Fluktuasi tingkat bunga. & 7,829 & $\mathrm{M}$ \\
\hline
\end{tabular}




\begin{tabular}{|c|c|c|c|}
\hline $\mathbf{R 7}$ & Peralatan cacat karena gangguan. & 7,171 & $\mathrm{~L}$ \\
\hline $\mathbf{R 8}$ & Ketidaktersediaan material. & 10,657 & $\mathrm{H}$ \\
\hline $\mathbf{R 9}$ & Kerusakan atau kehilangan material. & 8,429 & M \\
\hline R10 & Keterlambatan pengiriman material dari suplier. & 10,400 & $\mathrm{H}$ \\
\hline R11 & Kenaikan harga material. & 8,857 & M \\
\hline $\mathbf{R} 12$ & Volume material yang dikirim tidak tepat. & 7,514 & $\mathrm{~L}$ \\
\hline $\mathbf{R} 13$ & $\begin{array}{l}\text { Kurang tepatnya pengadaan material dan peralatan } \\
\text { (volume, jadwal, harga dan kualitas). }\end{array}$ & 7,600 & M \\
\hline R14 & Pemadaman listrik. & 7,086 & $\mathrm{~L}$ \\
\hline $\mathbf{R} 15$ & Pencurian terhadap material. & 6,657 & $\mathrm{~L}$ \\
\hline R16 & $\begin{array}{l}\text { Peralatan yang tidak sesuai dengan kondisi } \\
\text { lapangan. }\end{array}$ & 6,057 & $\mathrm{~L}$ \\
\hline $\mathbf{R} 17$ & Kesulitan mendapatkan material dan peralatan. & 6,971 & $\mathrm{~L}$ \\
\hline $\mathbf{R} 18$ & Timbulnya kemacetan di sekitar lokasi proyek. & 9,571 & M \\
\hline R19 & Kondisi lokasi site yang sulit. & 11,657 & $\mathrm{H}$ \\
\hline $\mathbf{R} 20$ & Perbedaan kondisi tanah dasar. & 8,543 & M \\
\hline $\mathbf{R} 21$ & Kondisi tanah yang tidak stabil. & 8,657 & M \\
\hline $\mathbf{R} 22$ & Kerusakan dalam pemasangan tiang pancang. & 9,171 & M \\
\hline $\mathbf{R} 23$ & Titik pancang yang tidak tepat dan bermasalah. & 8,343 & M \\
\hline $\mathbf{R} 24$ & Adanya tiang pancang yang patah/pecah. & 8,429 & M \\
\hline $\mathbf{R} 25$ & Meluapnya air tanah. & 8,829 & M \\
\hline $\mathbf{R} 26$ & Pengaruh tekanan angin pada pelaksanaan. & 6,829 & $\mathrm{~L}$ \\
\hline $\mathbf{R} 27$ & Penggelapan aset proyek. & 6,486 & $\mathrm{~L}$ \\
\hline $\mathbf{R} 28$ & $\begin{array}{l}\text { Kerusakan yang terjadi di daerah sekitar pada saat } \\
\text { pemancangan. }\end{array}$ & 6,886 & $\mathrm{~L}$ \\
\hline $\mathbf{R} 29$ & Kerusakan pada fasilitas transportasi di sekitar. & 6,543 & $\mathrm{~L}$ \\
\hline $\mathbf{R 3 0}$ & Kesalahan pada survey. & 8,086 & M \\
\hline R32 & Gangguan keamanan di lokasi proyek. & 7,114 & $\mathrm{~L}$ \\
\hline $\mathbf{R 3 3}$ & $\begin{array}{l}\text { Kesulitan pemasangan bekisting dan perancah di } \\
\text { ketinggian. }\end{array}$ & 8,543 & M \\
\hline R34 & Peyetelan dan perakitan besi yang tidak tepat. & 7,943 & M \\
\hline $\mathbf{R 3 5}$ & Pemadatan yang tidak merata pada saat pengecoran. & 8,971 & M \\
\hline R36 & Terjadinya lendutan pada balok struktur. & 8,543 & M \\
\hline R37 & Terjadinya patahan pada balok/kolom. & 7,000 & $\mathrm{~L}$ \\
\hline $\mathbf{R 3 8}$ & $\begin{array}{l}\text { Kemiringan struktur setelah mencapai ketinggian } \\
\text { tertentu. }\end{array}$ & 8,514 & M \\
\hline $\mathbf{R 4 0}$ & $\begin{array}{l}\text { Tidak tersedianya/kurangnya tenaga kerja } \\
\text { berkeahlian khusus. }\end{array}$ & 8,800 & M \\
\hline R41 & $\begin{array}{l}\text { Kegagalan kontraktor dalam memulai } \\
\text { proyek/pekerjaan sesuai jadwal. }\end{array}$ & 7,229 & $\mathrm{~L}$ \\
\hline $\mathbf{R} 42$ & Kesalahan estimasi biaya proyek. & 8,743 & M \\
\hline $\mathbf{R} 43$ & Kesalahan estimasi waktu pelaksanaan proyek. & 10,886 & $\mathrm{H}$ \\
\hline R44 & $\begin{array}{l}\text { Pungutan-pungutan lain yang tidak terduga dan } \\
\text { tidak dapat dihindari. }\end{array}$ & 7,514 & $\mathrm{~L}$ \\
\hline $\mathbf{R} 45$ & $\begin{array}{l}\text { Kontraktor terlambat memulai proyek/pekerjaan } \\
\text { karena kesalahan owner. }\end{array}$ & 7,000 & $\mathrm{~L}$ \\
\hline
\end{tabular}




\begin{tabular}{llcc}
\hline R46 & Kurangnya kontrol dan koordinasi dalam tim & 8,657 & M \\
R47 & Staff yang kurang berpengalaman. & 7,429 & L \\
R48 & Perubahan prioritas dalam program yang sudah & 6,971 & L \\
& berjalan. & & \\
R51 & Penggunaan desain yang belum teruji. & 7,486 & $\mathrm{~L}$ \\
R52 & Kesulitan penggunaan teknologi. & 7,257 & $\mathrm{~L}$ \\
R53 & Data desain tidak lengkap. & 8,743 & $\mathrm{M}$ \\
R54 & Ketelitian dan ketidaksesuaian spesifikasi detail & 8,057 & $\mathrm{M}$ \\
& desain. & & \\
R55 & Metode pelaksanaan yang salah. & 8,143 & $\mathrm{M}$ \\
R56 & Perubahan spesifikasi oleh owner. & 6,743 & $\mathrm{~L}$ \\
R57 & Eskalasi/Kenaikan Biaya Konstruksi. & 7,571 & $\mathrm{M}$ \\
R58 & Kenaikan harga tanah. & 6,600 & $\mathrm{~L}$ \\
R59 & Penundaan waktu konstruksi. & 6,800 & $\mathrm{~L}$ \\
R60 & Negosiasi harga tanah yang berlarut-larut. & 7,257 & $\mathrm{~L}$ \\
R61 & Bencana alam. & 5,486 & $\mathrm{~L}$ \\
R62 & Demonstrasi/huru-hara. & 5,771 & $\mathrm{~L}$ \\
R63 & Muka air terlalu tinggi. & 7,143 & $\mathrm{~L}$ \\
R64 & Protes lingkungan akibat gangguan. & 6,486 & $\mathrm{~L}$ \\
R65 & Bencana karena ulah manusia. & 7,743 & $\mathrm{M}$ \\
R66 & Pernyataan perang. & 6,229 & $\mathrm{~L}$ \\
R69 & Pemogokan karyawan. & 7,600 & $\mathrm{M}$ \\
\hline S6 & &
\end{tabular}

Sumber: Hasil Olahan

Dari perhitungan indeks level risiko didapat level risiko yang cukup tinggi dan patut dipertimbangkan $(\mathrm{H})$ yaitu sebanyak 4 variabel, serta level risiko yang signifikan (M) adalah 27 variabel dan level risiko yang rendah (L) adalah 29 variabel dapat diabaikan.

\section{Respon Risiko}

Berdasarkan hasil kuesioner tahap ketiga ini pada dasarnya hampir seluruh pakar setuju dengan keempat faktor dominan yang mempengaruhi terhadap pelaksanaan konstruksi jembatan. Maka faktor-faktor dominan tersebut memberikan pengaruh yang signifikan terhadap pelaksanaan konstruksi jembatan.

Hasil dari validasi kuesioner tahap ketiga yang dilakukan kepada pakar dapat dilihat pada tabel berikut:

Tabel 6. Hasil Kuesioner Tahap 4

\begin{tabular}{lccl}
\multicolumn{1}{c}{$\begin{array}{c}\text { Peristiwa Risiko } \\
\text { Dominan }\end{array}$} & $\begin{array}{c}\text { Pendapat } \\
\text { Pakar }\end{array}$ & \multicolumn{2}{c}{$\begin{array}{c}\text { Tindakan Pencegahan/Pengendalian terhadap } \\
\text { risiko }\end{array}$} \\
\hline $\begin{array}{l}\text { Ketidaktersediaan } \\
\text { material. }\end{array}$ & Setuju & - Melakukan subsitusi material. \\
& & - Melakukan bundling kontrak material \\
& & dengan supplier (SCM). \\
$\begin{array}{l}\text { Keterlambatan } \\
\text { pengiriman material } \\
\text { dari suplier. }\end{array}$ & Setuju & Re-engineering. \\
\hline
\end{tabular}




\begin{tabular}{|c|c|c|}
\hline $\begin{array}{l}\text { Peristiwa Risiko } \\
\text { Dominan }\end{array}$ & $\begin{array}{l}\text { Pendapat } \\
\text { Pakar }\end{array}$ & $\begin{array}{c}\text { Tindakan Pencegahan/Pengendalian terhadap } \\
\text { risiko }\end{array}$ \\
\hline $\begin{array}{l}\text { Kondisi lokasi site } \\
\text { yang sulit. }\end{array}$ & Setuju & $\begin{array}{l}\text { - Perencanaan akses atau detour/mobility. } \\
\text { - Survey. }\end{array}$ \\
\hline $\begin{array}{l}\text { Kesalahan estimasi } \\
\text { waktu pelaksanaan } \\
\text { proyek. }\end{array}$ & Setuju & $\begin{array}{l}\text { - Perekaman data dan perencanaan oleh } \\
\text { - } \text { expert team. } \\
\text { - } \text { Upgrading estimator. } \\
\text { - } \text { atas aspek pekerjaan. } \\
\text { - Mitigasi risiko dijalankan. } \\
\text { - Survey. }\end{array}$ \\
\hline
\end{tabular}

Sumber: Hasil Olahan.

\section{KESIMPULAN DAN SARAN}

\section{Kesimpulan}

Variabel risiko yang mempunyai level yang tinggi $(\mathrm{H})$ dikategorikan sebagai variabel yang mempunyai tingkat risiko yang tinggi dan patut diperhitungkan, yaitu:

1. Kondisi lokasi site yang sulit, dengan bobot paling tinggi yaitu 11,657

2. Kesalahan estimasi waktu pelaksanaan proyek, dengan bobot sebesar 10,886

3. Ketidaktersediaan material, dengan bobot sebesar 10,657

4. Keterlambatan pengiriman material dari suplier, dengan bobot sebesar 10,400

Berdasarkan hasil kuesioner tahap ketiga hampir seluruh pakar menyetujui bahwa keempat faktor dominan yang didapat dari analisa level risiko dapat mempengaruhi pelaksanaan konstruksi jembatan.

\section{Saran}

Untuk penelitian selanjutnya, dapat meneliti lebih spesifik lagi dengan melibatkan semua pihak yang terlibat dalam pelaksanaan pekerjaan konstruksi jembatan. Penelitian selanjutnya dapat menambahkan peristiwa risiko lainnya yang berhubungan dengan pelaksanaan konstruksi..

\section{DAFTAR PUSTAKA}

[1] A Guide to the Project Management Body of Knowledge (PMBOK Guide) (2008), 4th edition, Project Management Institute.

[2] Alam, Toni (2011), Identifikasi Peristiwa risikoProyek Rancang Bangun (Design and Build) pada PT. XYZ yang Berpengaruh terhadap Kinerja Waktu. Tesis Program Magister Teknik Sipil, Universitas Indonesia Jakarta.

[3] Darmawi, H (2000) Manajemen Risiko. Jakarta, Bumi Aksara, Jakarta.

[4] Endroyo, Bambang. "Peranan Manajemen K3 dalam Pencegahan Kecelakaan Kerja Konstruksi”. Jurnal Jurusan Teknik Sipil Universitas Negeri Semarang (UNNES).

[5] Flanagan. R dan Norma, George (1993), Risk Management and Construction, Blackwell Science, Australia. 
[6] Godfrey, Patrick S, Sir William Halcrow and Partners Ltd (1996), Control of Risk. A Guideto the Systemtic Management of Risk from Construction. Westminster London : Construction Industry Research and Information Association (CIRIA).

[7] Iriyanto, Santje M. "Risiko Keterlambatan Proses Pelaksanaan Konstruksi Jembatan di Kabupaten Jayapura". Jurnal USTJ Jayapura.

[8] Kerzner, Harold (2001), Project Management, a System Approach to planning, Scheduling, and Controlling (Seventh Edition). New York, Jon Wiley \& Sons.

[9] Kuncoro. 2005. Diktat kuliah dan panduan praktikum : Aplikasi Komputer Psokologi. Jakarta, Universitas Persada Indonesia Jakarta.

[10] Kurniawan, Bagus Y (2011), “Analisa Risiko Konstruksi pada Proyek Pembangunan Apartemen Petra Square Surabaya", Jurnal Tugas Akhir Jurusan Teknik Sipil Institut Teknologi Sepuluh Nopember (ITS) Surabaya.

[11]Labombang, Mastura (2011), "Manajemen Risiko dalam Proyek Konstruksi". Jurnal SMARTek vol 9, No 1.

[12] Nurlela (2012), Identifikasi dan Analisis Manajemen Risiko pada Proyek Pembangunan Infrastruktur Bangunan Gedung Bertingkat. Tesis Program Pascasarjana Universitas Gunadarma.

[13] Putri, Anggraini Heidy, Nugroho Priyo Negoro, dan Yudha Andrian S (2012), "Manajemen Risiko Proyek Publik yang Dibiayai Swasta (Studi Kasus: Proyek Penyediaan Air Minum di Wilayah X)". Jurnal Teknik POMITS Vol 1, No 1, (2012) 1-5. Institut Teknologi Sepuluh Nopember (ITS) Surabaya.

[14] Sjawal, Mansur dan I Putu Artama Wiguna (2009), “Analisis Risiko terhadap Biaya Pelaksanaan pada Proyek Konstruksi Jembatan di Provinsi Papua". Jurnal ISBN 978-979-18342-1-6, FTSP Institut Teknologi Sepuluh Nopember (ITS) Surabaya.

[15] Soeharto, I (2001), Manajemen Proyek Jilid 2. Dari Konseptual Sampai Operasional. Jakarta : Erlangga.

[16] Trihendradi, C (2012), Step by Step SPSS 20 Analisis Data Statistik. ANDI : Yogyakarta.

[17] Uyanto, Stanislaus S (2006), Pedoman Analisis Data dengan SPSS. Penerbit : Graha Ilmu. Yogyakarta,

[18] Wideman, R. Max (1992), Project and Program Risk Manajement, A Guide to Managing Project Risk and Opportunities, PMI.

[19] Yuntar, Kurniawan, Bagus (2011), "Analisis Risiko Konstruksi pada Proyek Pembangunan Apartemen Petra Square Surabaya”. Jurnal Tugas Akhir, Institut Teknologi Sepuluh November (ITS) Surabaya. 
Debbi, Andi, dan A'isyah, Analisis Manajemen Risiko Pada Pro ... 